\title{
Effect of Low Level Laser in Combination with Pneumatic Compression in Modulation of Swelling in Patients with Knee Hemoarthrosis
}

\author{
ALAA R. MORGAN, Ph.D. \\ The Department of Physical Therapy for Disturbance of Growth \& Development in Pediatrics \& its Surgeries, \\ Faculty of Physical Therapy, Cairo University
}

\begin{abstract}
Background: Low level laser in combination with intermittent Pneumatic compression have effect in modulation of swelling in cases with knee hemoarthrosis in hemophilic children.

Aim of this Study: To investigate the effect of low level laser in combination with intermittent pneumatic compression in modulation of swelling in cases with knee hemoarthrosis in hemophilic children (after successive three months of treatment).

Patients and Methods: Forty hemophilic children their age ranging from seven to fourteen years, divided randomly into two groups (Group A and Group B). Group A received selected physical therapy program only (stretching, and strengthening exercises), while the Group B received low level laser therapy and intermittent pneumatic compression in addition to the same program given to the Group A. The swelling parameter (tape measurement and range of motion), was measured before and after successive three months of treatment.
\end{abstract}

Statistical Analysis: The collected data of the current study was statistically treated by the student's $t$-test for comparison of means of two independent groups. The alpha point of 0.05 was used as a level of statistical significance (when $p<0.05$, the difference is significant and when $p<0.01$, difference is highly significant); Minitab version 13 was the used statistical program.

Results: The study revealed significant improvement in most of the measured variables of the two groups, but in Group B the improvement was significantly increased more than Group A.

Conclusion: It may conclude that low level laser therapy in combination with intermittent pneumatic compression is an effective additional tools to physical therapy program in treating swelling in cases with knee hemoarthrosis of hemo-

Correspondence to: Dr. Alaa R. Morgan, The Department of Physical Therapy for Disturbance of Growth \& Development in Pediatrics \& its Surgeries, Faculty of Physical Therapy, Cairo University philic children as it plays an important role in decreasing swelling of the knee joint.

Key Words: Low level laser - Intermittent pneumatic compression - Hemophilia - Swelling - Knee hemoarthrosis.

\section{Introduction}

HEMOPHILIA is an $\mathrm{x}$-linked heritable coagulopathy with an ordinary prevalence of approximately 1 in 10,000 people. The 2 most common forms are factor viii deficiency or hemophilia a, which accommodates approximately eighty $\%$ of instances and component ix deficiency or hemophilia $b$, which accommodates about $20 \%$ of instances [1].

The occurrence of hemophilia a (classical) is $1 / 5000$ male births, and that of hemophilia $b$ (christmas disorder) is 1 in 25,000 about, $30 \%$ of the sufferers have no circle of relatives history and are a end result of de novo mutations [1].

The maximum not unusual manifestation of hemophilia is hemarthrosis, or bleeding within the joint space. The ankles, knees, and elbows are maximum typically worried, no matter the reality that the shoulders, wrists, and hips can also be affected. Worried joints are commonly heat, swollen, and smooth, with confined range of movement $[2,3]$.

Sufferers with excessive ailment have bleeding symptoms from early formative years that can consist of bleeding from circumcision in neonates, nose or mouth bleeding in babies, exaggerated bruising or palpable smooth tissue swelling from the trivial traumas of regular formative years sports, and spontaneous, painful hemarthoses of the joints (especially knees, elbows, and ankles) [4]. 
The most ordinary manifestation of hemophilia is articular bleeding (hemarthrosis). When articular bleeding (hemarthrosis). While hemarthroses become frequent and/or excessive, the synovium might not be able to reabsorb the blood. To compensate for such reabsorptive deficiency, the synovium will hypertrophy, resulting in what's called persistent hemophilic synovitis [5]

The everyday joint tablet is covered by means of synovium a skinny, moist, off white membrane that secretes synovial fluid for joint lubrication. While blood leaks into joint, the pill turns into distended inflicting swelling, pain, warmth and stiffness [6]

Persistent irritation causes abnormalities in joint structure and characteristic. Expanded manufacturing of synovial fluid stretches and weakens the joint tablet and adjoining structures. Erosions in the articular cartilage and subchondral bone cause irregularities in the joint surface which can result in drawback of variety of motion. Also, joint contractures result from intra-articular adhesions and fibrosis of adjacent tendons [6].

Physiotherapy and rehabilitation treatment seek to alleviate the pain and swelling to restore or maintain variety of motion, mobility, and function. Mild joint mobilization and correction of imbalances amongst muscle companies assist to reap those desires [7].

Compression remedy is one of the most usually used treatment modalities in sufferers with leg edema, and may improve the close by circulatory situations. Compression treatment, can decorate the gentle tissue blood deliver disturbances associated with the post-operative leg swelling amongst patients gift method arterial peripheral thru-pass surgical operation [8].

Impact of intermittent pneumatic compression is its capacity affect on peripheral blood go with the flow because of the repeated compression of the sympathetic nerves receptors (that are also answerable for the precapillary sphincter anxiety) [8].

Effects were concluded that laser gives extensive effect on cells and cell features including restore methods and neurotransmitter release. Clinically this can be expressed as an enhancement of wound recovery, nerve repair, and as an antiinflammatory and analgesic [9].

LLLT is a secure, non-invasive, green and efficacious method to reduce pain and swelling and to growth joint mobility in patients laid low with heberden's and bourchard's osteo arthritis [10]

\section{Subjects and Methods}

The study involved forty hemophilic children have knee hemoarthroses; age ranged from 10 to 15 years participated in this study. They were selected from Faculty of Physical Therapy Cairo University Outpatient Clinic and Elbhose Center. The study was conducted during November 2016 to May 2017. The patients were selected according to the following criteria: All of the patients have history of knee joint affection as bleeding and swelling ranges from mild to moderate degree, patients are able to walk with variable degree of limitation, they have no impairment of sensation or other neurological or psychological problems, they are clinically and medically stable and they are able to understand the requirements of the study. Patients were excluded if they had advanced radiographic changes (bone destruction, bony ankylosis and knee joint subluxation), who had congenital or acquired skeletal deformities or patients who had any cardiopulmonary dysfunctions and who had any neurological deficits such as convulsions, involuntary movements or receiving muscle relaxants.

\section{Design of the study:}

This study is a randomized controlled trial, pretest and post test design study. All patients were selected from Faculty of Physical Therapy, Cairo University Outpatient Clinic and Elbhose Center. The parents of patients signed informed consent forms giving agreement for participation and publications of the study results. The patients were randomly divided into two groups: Group A received selected physical therapy program only (stretching, and strengthening exercises), while the Group B received low level laser therapy and intermittent pneumatic compression in addition to the same program given to the Group A.

\section{Procedures:}

Each participant underwent the same evaluation, which was performed by the same therapist at the beginning and end of the treatment period ( 3 months). All participants were asked to maintain their activity levels during the period of the study. Evaluation procedures included the following:

\section{For assessment:}

1- Tape measurement: Tape measurement was used to measure circumference of the knee in centimeters. 


\section{2- A digital uni dimensional Egyptian made elec- trogoniometer: The device consists of:}

A- Two copper arms, with length of $25 \mathrm{~cm}$ and width of $5 \mathrm{~cm}$ placed parallel to the longitudinal axe of the body segment.

B- A potentiometer placed between the two copper arms with one arm strapped to the proximal limb segment and the other strapped to the distal limb segment. The potentiometer, which is placed over the joint, provides a varying of electrical impulses, depending on the instantaneous angle between the two limb segments. This electrical impulse information is then interfaced to an analogto-digital converter in a personal computer to plot joint angle information.

C- A digital display is connected to the potentiometer through insulated electrical wires by sockets in digital display unit and metal jacks at the end of the electrical wires. This display converts each one degree of angular displacement to one electrical volt.

D- Four straps are used for fixation and stabilization of the instrument around the knee joint.

E- The source of power supply was from direct current with two batteries each of 9 volts.

\section{Treatment procedures:}

Group (A): All the subjects of that group received traditional treatment program for hemophilia (stretching exercises for hip flexors, adductors, hamstrings, and cuff muscles in the lower limbs, strengthening exercises using bicycle ergometer training for 3 minutes as a warming up then gradually increasing resistance for about 14 minutes and end the treatment session with unloaded cycling for another 3 minutes as a cooling down, treadmill training, walk on the treadmill with a speed of 1.5 kilometers/hour and 0 degree of inclination for 5 minutes as a warming up. Then, the speed was increased gradually to reach 3 kilometers/hour and 10 degrees inclination for 15 minutes). And group (B): Subjects of that group received low level laser. The options of the appliance were adjusted with frequency $(700 \mathrm{HZ})$, and for 11 minutes and intermittent pneumatic compression applied to patients in the supine position and with slight legs elevation. Chamber cuffs (Kendall SCD Express Foot Cuff) were used and in all patients lower limbs compression was applied. The compression cycles consisted of $4 \mathrm{~s}$ of cuff inflation, a $1 \mathrm{~s}$ pressure plateau and $15 \mathrm{~s}$ of cuff deflation. The maximum pressure was individualized to reach a value that was $10 \mathrm{mmHg}$ lower than the diastolic pressure measured on the toe arteries (the pressure values ranged from 50 to $72 \mathrm{mmHg}$; mean $59 \mathrm{mmHg}$ ) in addition to the same program given to the Group A. The child received the sessions in a frequency of 3 sessions per week.

\section{Statistical analysis:}

Descriptive statistics (mean \pm SD) was used for all participants in the two groups to study all variables. Independent $t$-test was used to compare the pretreatment and post-treatment of swelling between the two groups of the study. Paired $t$-test was used to compare the before and after treatment results in the same group for swelling variable. $p$ value less than 0.05 was considered statistically significant.

\section{Results}

None of the patients in either treatment groups dropped out throughout the study period. There was no significant difference $(p>0.05)$ between both groups. The study was carried out on two groups of equal number Group A and Group B, 15 patients' each. The ages (mean \pm standard deviation) of Group A and Group B were 11.54 \pm 1.647 and $11.7 \pm 1.813$ years, respectively.

\section{Knee swelling (circumference measurements):}

Table (1) and Fig. (1) identify that the differences between Group A and Group B; in their pretreatment values of right and left knees swelling assessment were statistically insignificant.

Range of motion of the knee joint (electrogoniometer measurements):

Statistical analyses for both groups were studied before treatment. The pre-treatment results showed no significant difference in range of motion of the knee joint, as shown in (Table 2) and Figs. $(2,3)$.

\section{Knee swelling for Group A pre and post treat-} ment:

Statistical analyses for Group A were studied before and after treatment. The results showed significant differences in the post treatment results of swelling of the knee joint when compared to the pre-treatment results as shown in (Table 3 ) and Fig. (4).

Knee swelling for Group B pre and post treatment:

Table (4) and Fig. (5) identify that the differences between Group B in their pre and posttreatment values of right and left knees swelling assessment were statistically significant. 
Range of motion of the knee joint for Group A pre and post-treatment:

Table (5) and Figs. $(6,7)$ identify that the differences between Group A in their pre and posttreatment values of right and left knees range of motion assessment were statistically significant.

Range of motion of the knee joint for Group B pre and post-treatment:

Statistical analyses for Group B were studied before and after treatment. The post-treatment results of range of motion of the knee joint showed significant improvement as shown in (Table 6) and Figs. $(8,9)$.

\section{Knee swelling for both groups post-treatment:}

Table (7) and Fig. (10) identify significant improvement in Group B more than Group A in their post-treatment values of right and left knees swelling assessment.

\section{Range of motion of the knee joint for both} groups post-treatment:

Statistical analyses for both groups were studied after treatment. The post treatment results showed significant improvement in range of motion of the knee joint in Group B more than in Group A, as shown in (Table 8) and Figs. $(11,12)$.

Table (1): Comparison between mean values of pre-treatment results of swelling of right and left knee joint in both groups.

\begin{tabular}{|c|c|c|c|c|c|c|c|}
\hline $\begin{array}{l}\text { Affected } \\
\text { side }\end{array}$ & $\begin{array}{c}\text { Level of } \\
\text { measurement }\end{array}$ & $\begin{array}{c}\text { Group A } \\
\text { Mean } \pm \text { SD } \\
\text { CM }\end{array}$ & $\begin{array}{c}\text { Group B } \\
\text { Mean } \pm \text { SD } \\
\text { CM }\end{array}$ & MD & $\begin{array}{c}t- \\
\text { value }\end{array}$ & $\begin{array}{c}p- \\
\text { value }\end{array}$ & Significance \\
\hline Right & Mid Patella & $28.98 \pm 5.17$ & $28.65 \pm 5.42$ & 0 & 0.14 & 0.71 & NS \\
\hline knee & Above Patella & $31.88 \pm 2.17$ & $31.90 \pm 2.61$ & 0.24 & 0.34 & 0.77 & NS \\
\hline Left & Mid Patella & $28.35 \pm 3.31$ & $28.5 \pm 1.15$ & -0.31 & -0.41 & 0.63 & NS \\
\hline Knee & Above Patella & $31.81 \pm 1.3$ & $31.50 \pm 1.7$ & -0.08 & -0.37 & 0.85 & NS \\
\hline $\begin{array}{ll}\mathrm{X} & : \text { Mea } \\
\text { SD } & : \text { Stan } \\
\text { MD }: \text { Mea }\end{array}$ & $\begin{array}{l}\text { Deviation. } \\
\text { fference. }\end{array}$ & $\begin{array}{c}p- \\
t- \\
\mathrm{N}\end{array}$ & $\begin{array}{l}\text { de : Probabilit } \\
\text { e : Unpaired } \\
\text { : Non Signi }\end{array}$ & & & & \\
\hline
\end{tabular}

Table (2): Comparison between mean values of pre-treatment results of range of motion of right and left knee joints in both groups.

\begin{tabular}{llcccccc}
\hline $\begin{array}{l}\text { Affected } \\
\text { side }\end{array}$ & $\begin{array}{c}\text { Level of } \\
\text { measurement }\end{array}$ & $\begin{array}{c}\text { Group A } \\
\text { Mean } \pm \text { SD }\end{array}$ & $\begin{array}{c}\text { Group B } \\
\text { Mean } \pm \text { SD } \\
\text { CM }\end{array}$ & MD & $\begin{array}{c}t \text { - } \\
\text { value }\end{array}$ & $\begin{array}{c}p \text { - } \\
\text { value }\end{array}$ & Significance \\
\hline Right & Flexion & $126.85 \pm 4.96$ & $127.10 \pm 4.71$ & 0.25 & 0.13 & 0.81 & NS \\
knee & Extension & $2.01 \pm 0.482$ & $2.2 \pm 0.554$ & 0.35 & 0.31 & 0.27 & NS \\
Left & Flexion & $126.95 \pm 4.78$ & $127.20 \pm 4.58$ & 0.44 & -0.31 & 0.83 & NS \\
Knee & Extension & $2.10 \pm 0.486$ & $2.21 \pm 0.513$ & 0.28 & -0.47 & 0.35 & NS \\
\hline
\end{tabular}

Table (3): Comparison between mean values of pre and post-treatment results of swelling of right and left knee joint in Group A.

\begin{tabular}{|c|c|c|c|c|c|c|c|}
\hline $\begin{array}{l}\text { Affected } \\
\text { side }\end{array}$ & $\begin{array}{c}\text { Level of } \\
\text { measurement }\end{array}$ & $\begin{array}{c}\text { Pre } \\
\text { Mean } \pm \text { SD } \\
\text { CM }\end{array}$ & $\begin{array}{c}\text { Post } \\
\text { Mean } \pm \text { SD } \\
\text { CM }\end{array}$ & MD & $\begin{array}{c}t- \\
\text { value }\end{array}$ & $\begin{array}{c}p- \\
\text { value }\end{array}$ & Significance \\
\hline Right & Mid Patella & $28.98 \pm 5.17$ & $26.83 \pm 6.76$ & 0 & 2.14 & 0.021 & $\mathrm{~S}$ \\
\hline knee & Above Patella & $31.88 \pm 2.17$ & $29.73 \pm 4.20$ & 0 & 2.41 & 0.02 & $\mathrm{~S}$ \\
\hline Left & Mid Patella & $28.35 \pm 3.31$ & $25.48 \pm 2.14$ & 0 & 2.11 & 0.01 & $S$ \\
\hline Knee & Above Patella & $31.81 \pm 1.3$ & $29.62 \pm 1.80$ & 0 & 2.28 & 0.021 & $\mathrm{~S}$ \\
\hline
\end{tabular}


Table (4): Comparison between mean values of pre and post-treatment results of swelling of right and left knee joint in Group B.

\begin{tabular}{llcccccc}
\hline $\begin{array}{l}\text { Affected } \\
\text { side }\end{array}$ & $\begin{array}{c}\text { Level of } \\
\text { measurement }\end{array}$ & $\begin{array}{c}\text { Pre } \\
\text { Mean } \pm \text { SD } \\
\text { CM }\end{array}$ & $\begin{array}{c}\text { Post } \\
\text { Mean } \pm \text { SD } \\
\text { CM }\end{array}$ & MD & $\begin{array}{c}t \text { - } \\
\text { value }\end{array}$ & $\begin{array}{c}p \text { - } \\
\text { value }\end{array}$ & Significance \\
\hline Right & Mid Patella & $28.65 \pm 5.42$ & $21.98 \pm 8.70$ & 0 & 2.16 & 0.000 & S \\
knee & Above Patella & $31.90 \pm 2.61$ & $24.75 \pm 2.18$ & 0 & 15.09 & 0.001 & S \\
Left & Mid Patella & $28.5 \pm 1.15$ & $23.05 \pm 2.25$ & 0 & 7.96 & 0.001 & S \\
Knee & Above Patella & $31.50 \pm 1.7$ & $22.96 \pm 2.16$ & 0 & 12.99 & 0.000 & S \\
\hline
\end{tabular}

Table (5): Comparison between mean values of pre and post-treatment results of range of motion of right and left knee joints in Group A.

\begin{tabular}{llcccccc}
\hline $\begin{array}{l}\text { Affected } \\
\text { side }\end{array}$ & $\begin{array}{c}\text { Level of } \\
\text { measurement }\end{array}$ & $\begin{array}{c}\text { Mean } \pm \text { SD } \\
\text { CM }\end{array}$ & $\begin{array}{c}\text { Peast } \\
\text { CM SD }\end{array}$ & MD & $\begin{array}{c}t \text { - } \\
\text { value }\end{array}$ & $\begin{array}{c}p \text { - } \\
\text { value }\end{array}$ & Significance \\
\hline Right & Flexion & $126.85 \pm 4.96$ & $129.95 \pm 5.83$ & 0.15 & 2.26 & 0.02 & $\mathrm{~S}$ \\
knee & Extension & $2.01 \pm 0.482$ & $1.39 \pm 1.508$ & 0.34 & 2.16 & 0.03 & $\mathrm{~S}$ \\
Left & Flexion & $126.95 \pm 4.78$ & $129.94 \pm 4.13$ & 0.26 & 2.13 & 0.02 & $\mathrm{~S}$ \\
Knee & Extension & $2.10 \pm 0.486$ & $1.26 \pm 1.42$ & 0.38 & 2.13 & 0.03 & $\mathrm{~S}$ \\
\hline
\end{tabular}

Table (6): Comparison between mean values of pre and post-treatment results of range of motion of right and left knee joints in Group B.

\begin{tabular}{llllllll}
\hline $\begin{array}{l}\text { Affected } \\
\text { side }\end{array}$ & $\begin{array}{c}\text { Level of } \\
\text { measurement }\end{array}$ & $\begin{array}{c}\text { Mean } \pm \text { SD } \\
\text { CM }\end{array}$ & $\begin{array}{c}\text { Mean } \pm \text { SD } \\
\text { CM }\end{array}$ & MD & $\begin{array}{c}t \text { - } \\
\text { value }\end{array}$ & $\begin{array}{c}p \text { - } \\
\text { value }\end{array}$ & Significance \\
\hline Right & Flexion & $127.10 \pm 4.71$ & $134.15 \pm 1.66$ & 0.14 & -4.78 & 0.004 & S \\
knee & Extension & $2.2 \pm 0.554$ & $1.02 \pm 0.66$ & 0.24 & 5.89 & 0.01 & $\mathrm{~S}$ \\
Left & Flexion & $127.20 \pm 4.58$ & $135 \pm 1.47$ & 0.18 & -6.37 & 0.004 & $\mathrm{~S}$ \\
Knee & Extension & $2.21 \pm 0.513$ & $1.03 \pm 0.77$ & 0.28 & 6.84 & 0.01 & $\mathrm{~S}$ \\
\hline
\end{tabular}

Table (7): Comparison between mean values of post-treatment results of swelling of right and left knee joint in both groups.

\begin{tabular}{llcccccc}
\hline $\begin{array}{l}\text { Affected } \\
\text { side }\end{array}$ & $\begin{array}{c}\text { Level of } \\
\text { measurement }\end{array}$ & $\begin{array}{c}\text { Group A } \\
\text { Mean } \pm \text { SD } \\
\text { CM }\end{array}$ & $\begin{array}{c}\text { Group B } \\
\text { Mean } \pm \text { SD } \\
\text { CM }\end{array}$ & MD & $\begin{array}{c}t \text { - } \\
\text { value }\end{array}$ & $\begin{array}{c}p \text { - } \\
\text { value }\end{array}$ & Significance \\
\hline Right & Mid Patella & $26.83 \pm 6.76$ & $21.98 \pm 8.70$ & 0 & 3.11 & 0.001 & $\mathrm{~S}$ \\
knee & Above Patella & $29.73 \pm 4.20$ & $24.75 \pm 2.18$ & 0 & 2.21 & 0.001 & $\mathrm{~S}$ \\
Left & Mid Patella & $25.48 \pm 2.14$ & $23.05 \pm 2.25$ & 0 & 3.51 & 0.03 & $\mathrm{~S}$ \\
Knee & Above Patella & $29.62 \pm 1.80$ & $22.96 \pm 2.16$ & 0 & 2.18 & 0.000 & $\mathrm{~S}$ \\
\hline
\end{tabular}

Table (8): Comparison between mean values of post-treatment results of range of motion of right and left knee joints in both groups.

\begin{tabular}{llllllll}
\hline $\begin{array}{l}\text { Affected } \\
\text { side }\end{array}$ & $\begin{array}{c}\text { Level of } \\
\text { measurement }\end{array}$ & $\begin{array}{c}\text { Group A } \\
\text { Mean } \pm \text { SD } \\
\text { CM }\end{array}$ & $\begin{array}{c}\text { Group B } \\
\text { Mean } \pm \text { SD } \\
\text { CM }\end{array}$ & MD & $\begin{array}{c}t \text { - } \\
\text { value }\end{array}$ & $\begin{array}{c}p \text { - } \\
\text { value }\end{array}$ & Significance \\
\hline Right & Flexion & $129.95 \pm 5.83$ & $134.15 \pm 1.66$ & 0.12 & 3.68 & 0.003 & S \\
knee & Extension & $1.39 \pm 1.508$ & $1.02 \pm 0.66$ & 0.18 & 3.89 & 0.06 & NS \\
Left & Flexion & $129.94 \pm 4.13$ & $135 \pm 1.47$ & 0.18 & 5.31 & 0.002 & S \\
Knee & Extension & $1.26 \pm 1.42$ & $1.03 \pm 0.77$ & 0.28 & 4.82 & 0.06 & NS \\
\hline
\end{tabular}




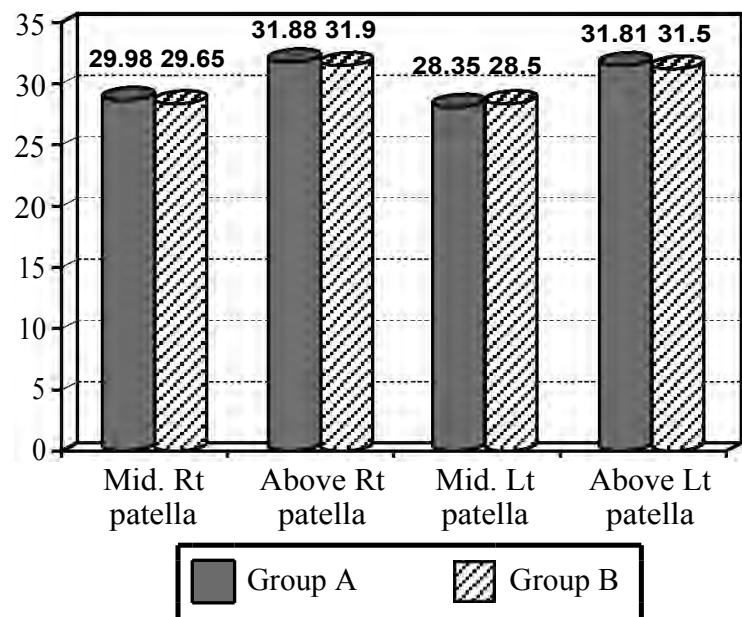

Fig. (1): The mean value of pre-treatment of swelling of right and left knee joint in both groups.

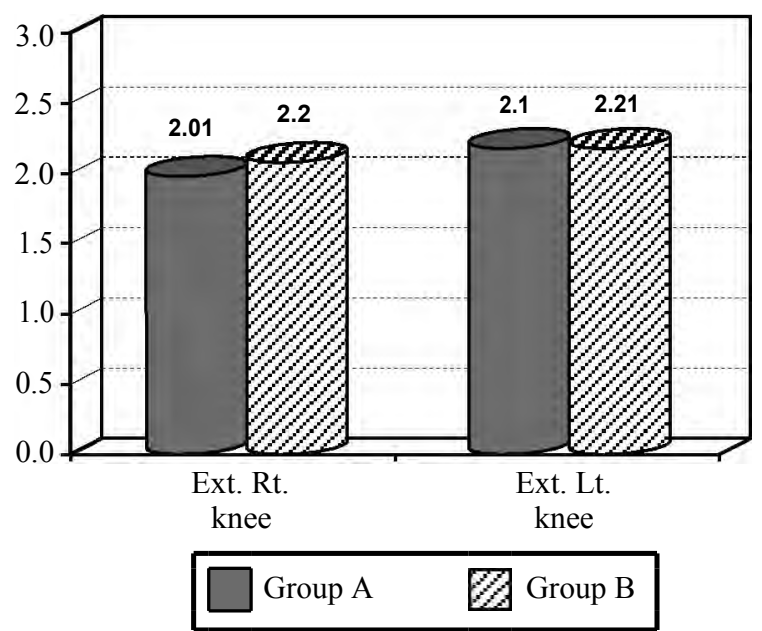

Fig. (3): The mean value of pre-treatment of range of motion for both lower limbs flexors for both groups.

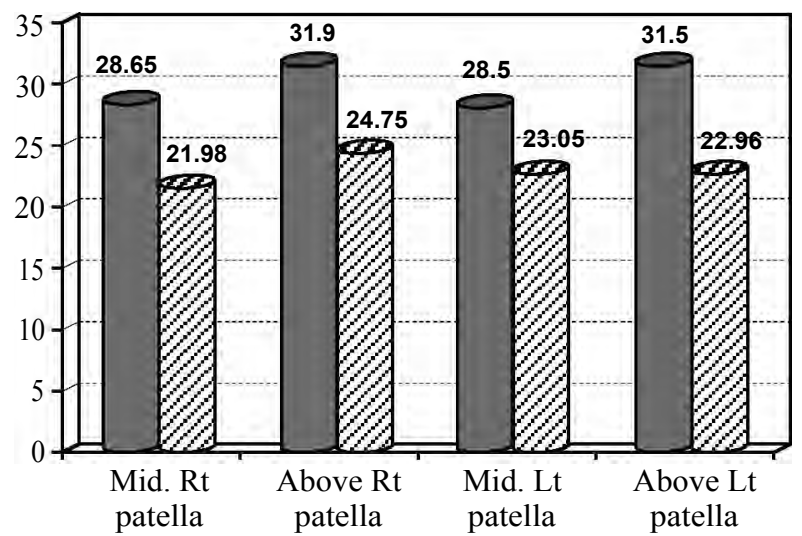

Pre-treatment $\quad Z$ Post-treatment

Fig. (5): The mean value of pre and post-treatment of swelling of right and left knee joint in Group B.

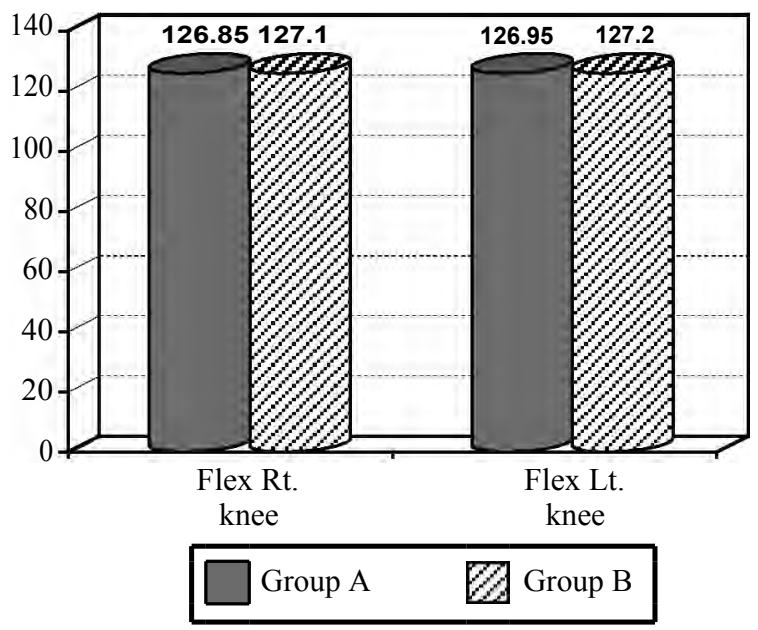

Fig. (2): The mean value of pre-treatment of range of motion for both lower limbs flexors for both groups.

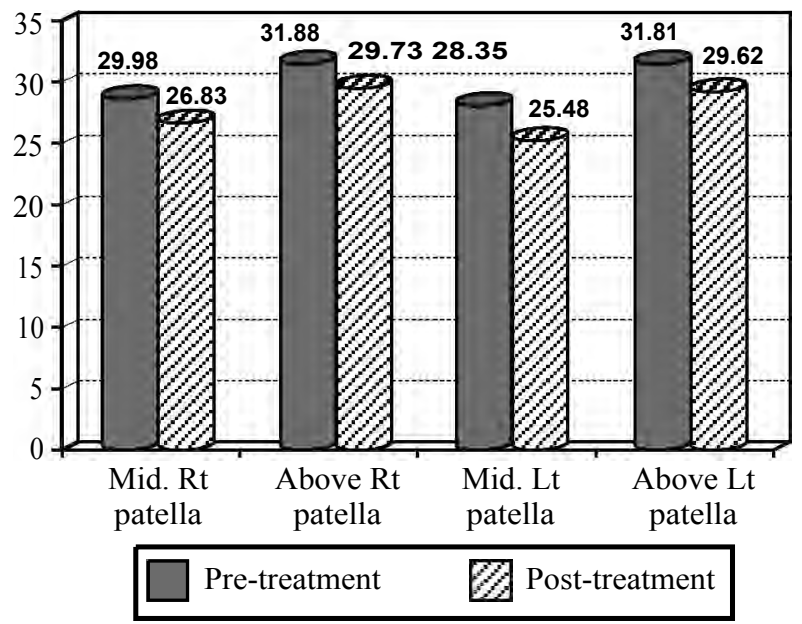

Fig. (4): The mean value of pre and post-treatment of swelling of right and left knee joint in Group A.

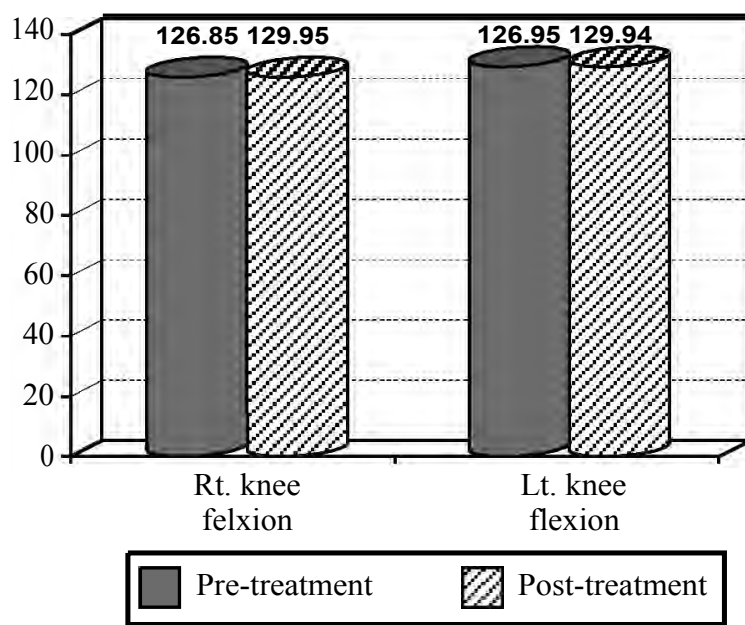

Fig. (6): The mean value of pre and post-treatment of range of motion of right and left knee joint flexion in Group A. 


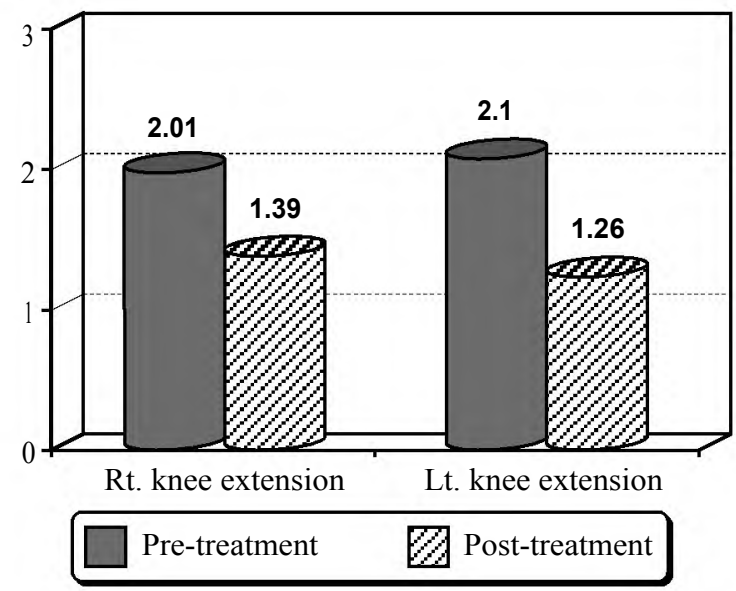

Fig. (7): The mean value of pre and post-treatment of range of motion of right and left knee joint extension in Group A.

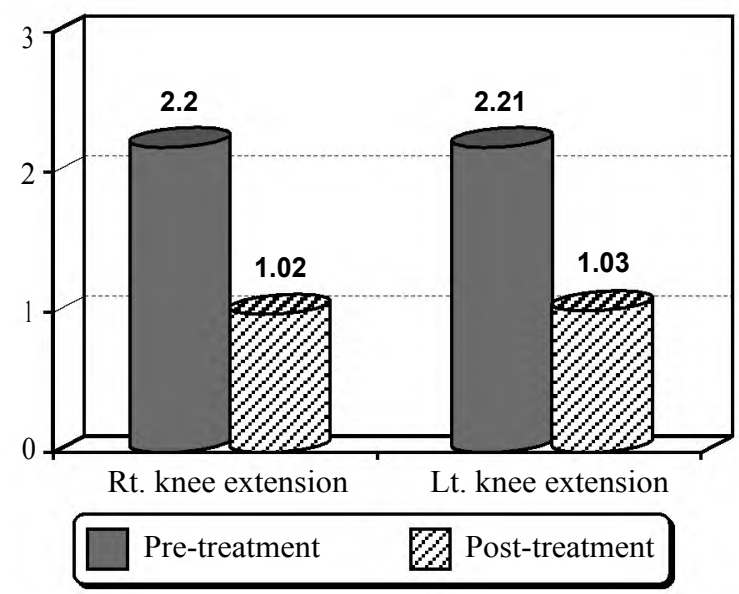

Fig. (9): The mean value of pre and post-treatment of range of motion of right and left knee joint extension in Group B.

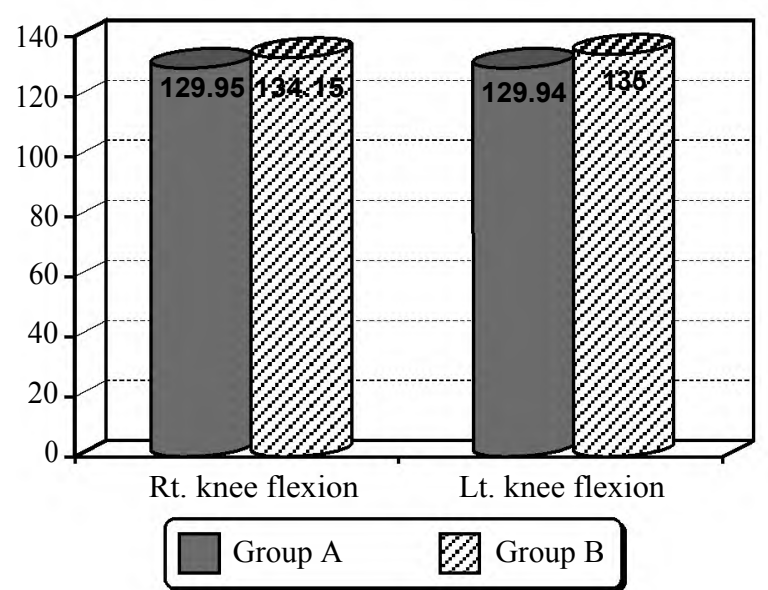

Fig. (11): The mean value of post-treatment of range of motion of right and left knee joint flexion in both groups.

\section{Discussion}

Haemophilia is an inherited bleeding illness because of a deficiency in one of the blood coag-

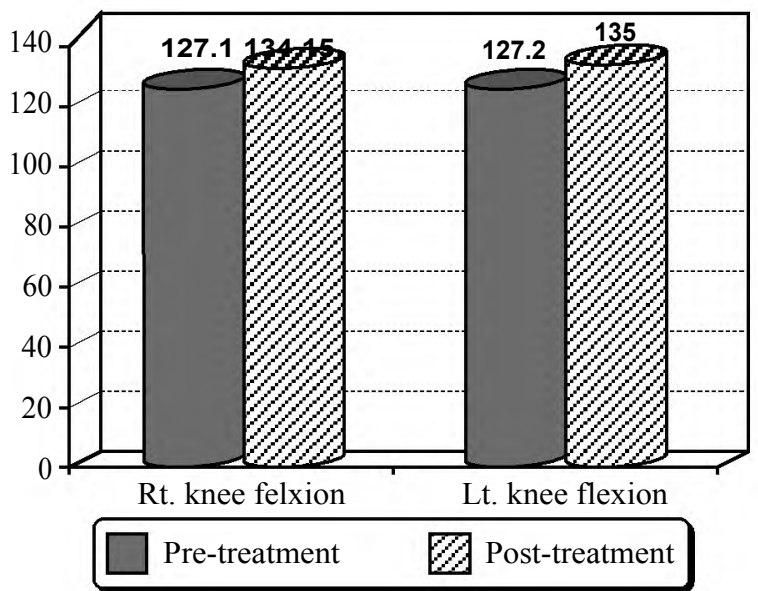

Fig. (8): The mean value of pre and post-treatment of range of motion of right and left knee joint flexion in Group B.

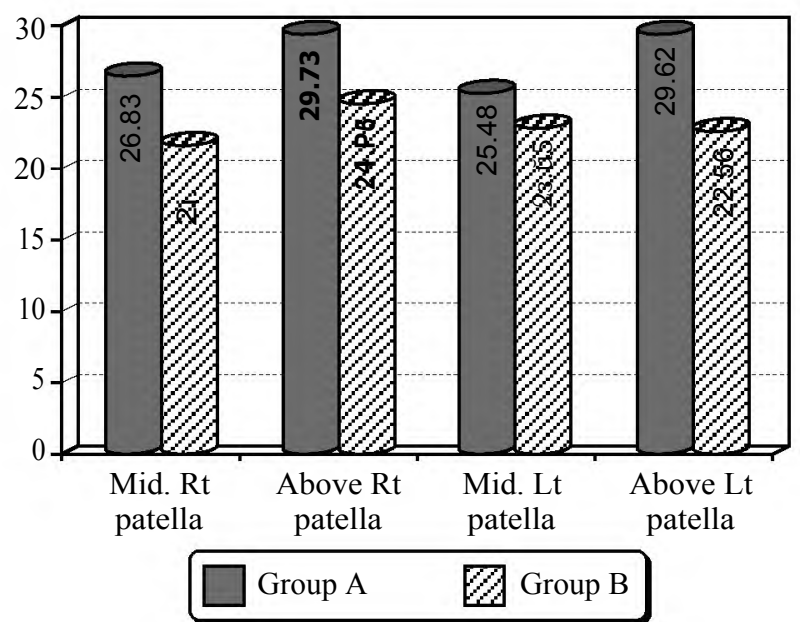

Fig. (10): The mean value of post-treatment of swelling of right and left knee joint in both groups.

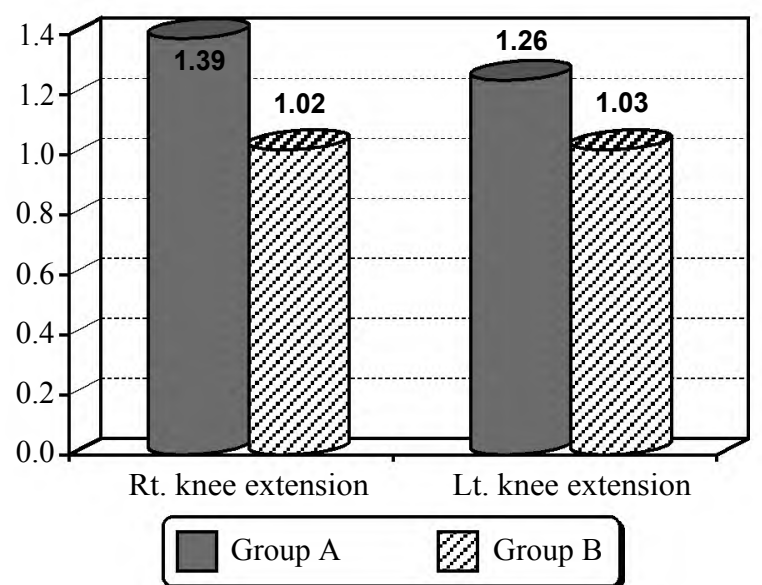

Fig. (12): The mean value of post-treatment of range of motion of right and left knee joint extension in both groups.

ulation elements. For human beings laid low with intense haemophilia, the deficiency can cause spontaneous internal bleeding [11]. Joint bleed (hemarthrosis) has been found to be the most 
common (82-100\%) presenting feature followed by skin bleeds $(77-90 \%)$ [12].

Joint bleed (hemarthrosis) has been determined to be the maximum common (eighty two-one hundred\%) offering feature followed by way of skin bleeds (seventy seven-90\%). Sufferers with the mild and moderate disease typically bleed after big trauma or principal surgical treatment; those with the excessive form might also bleed spontaneously or after little trauma [13].

Historically it is notion that recurrent hemarthroses stimulates synovial proliferation and hypertrophy with release of hydrolytic enzymes. Those enzymes together with accelerated ranges of prostaglandins assist preserve the inflammatory reaction inside the synovium $[\mathbf{1 4 , 1 5}]$.

The sizable improvement in swelling on the give up of treatment for hemophilic kids in Group (A) can be due to effect of using ultrasound which has an effect at the inflammatory technique. This could be resulting from an ultrasonically triggered increase in release of platelets and macrophages. It also can improve pain and encourages the reabsorption of hemarthroses [16,17].

David et al., suggested that ultrasound has been used to help melt and breakdown the hematoma. He used a therapeutic dose of 1 . Five $\mathrm{wcm}^{2}$ for 10 minutes thru a coupling agent or below water [18]

There are good sized development in swelling and variety of movement at the cease of treatment program for hemophilic children in Group (B) this can be attributed to the impact of low stage laser on inhibition of each the formation of edema and inflammatory cells migration into muscle tissue tissue and adjoining conjunctive tissue and effect intermittent compression growth within the microcirculation waft [17]

Laser irradiation may also have a beneficial impact on wound recuperation of bone through accelerating bone regeneration stimulating formation of trabecular osteoid tissue growing vascularization and promoting quicker metabolism and response of bone callus by modulation of the feature of osteocytes [19].

This remark is available in settlement with conlan and ana maria barbosa who suggested that low level laser turned into powerful in decreasing edema formation and suggesting a Bargain in the inflammatory reaction. The full variety of leukocytes and polymorphonuclear cells is notably reduced by means of the use of low level laser [20,21]
LLLT can modulate immune reaction, and to boost up the regeneration of broken tissue [22]

Additionally the development in swelling and variety of motion at the cease of treatment application for hemophilic kids in Group (B) this will be attributed to the impact of intermittent pneumatic compression because it increases within the microcirculation float $[8]$.

Intermittent pneumatic compression improve the reactive vessel dilatation in reaction to exercising the veno-arterial reflex can be modified because of discount of the vein system reservoir blood volume which is associated with the effective have an effect on of intermittent compression on the venous outflow $[23,24]$.

This commentary comes in agreement with de haro $\mathrm{j}$, acin $\mathrm{f}$, who mentioned that intermittent pneumatic compression changed into effective in lowering edema formation and can improve the tender tissue blood supply disturbances [25].

\section{Conclusion:}

The most ordinary manifestation of hemophilia is articular bleeding (hemarthrosis). When articular bleeding (hemarthrosis). Whilst hemarthroses come to be frequent and/or intense, the synovium won't be capable of reabsorb the blood. To make amends for such reabsorptive deficiency, the synovium will hypertrophy, ensuing in what's referred to as persistent hemophilic synovitis [5].

Low level laser and intermittent compression intervention has been recommended for the treatment knee hemoarhrosis in hemophlic children. Early intervention should attempt to increase physical activity. The emphasis should be laid on decrease pain and increase range of motion. It is very encouraging that low level laser and intermittent Pneumatic compression had improvent effect in conjunction with traditional treatment program for hemophilia [26-28]

In summary, our results suggest that low level laser and intermittent Pneumatic compression intervention in children with knee hemolathrosis can lead to a significant improvement of range of motion.

\section{References}

1- VIKAS PAYAL1, PRAMOD SHARMA1, VISHNU GOY AL, et al.: Clinical profile of hemophilia patients in Jodhpur Region, 3ed, 323-35, 2016.

2- SUZANIN K., DRALW V. and ROBERT J.: Physical therapy for children, Hemophilia, 3ed, 323-35, 2006. 
3- BROWN D.: Conginetal bleeding disorders. Curr. Probl. Pediatric Adolescnse Health Care, 35: L 38-62, 2005.

4- TAMMUELLA SINGLETON, M.D., REBECCA KRUSEJARRY, M.D., and CINDY LEISSINGER, M.D.: Emergency Department Care for patients with hemophilia and von willebrand disease, 2008.

5- RODRIGUEZ-MERCHAN E.C., MAGALLON M., GALINDO E., et al.: Hemophilic synovitis of the knee and elbow. Clin. Orthop., 343: 47-53, 2008.

6- PETTY R. and CASSIDY J.: "Hemophilia". In: Textbook of pediatric rheumatology. Cassidy J. and Petty R. 4 th edition. W.B. Saunders Company, New York, Chapter 12 pp. 218-321, 2003.

7- BUZZARD B.: Physiotherapy management of hemophilia in children, In: Rodriguez Merchant E., Goddard N. and Lee C., ${ }^{\text {rd }}$ ed. Muscloskeletal aspects of haemophilia. Oxford: Black Well Science, 169-75, 2000.

8- KATARZYNA PAWLACZYK, MARCIN GABRIEL TOMASZ URBANEK, et al.: Effects of Intermittent Pneumatic Compression on Reduction of Postoperative Lower Extremity Edema and Normalization of Foot Microcirculation Flow in Patients Undergoing Arterial Revascularization, Med. Sci. Monit. Dec., 21 (21): 3986-92, 2015.

9- BAXTER G.D., BELL A.J., and ALLEN J.M.: Low level laser therapy Current clinical practice in Northern Ireland. Physiotherapy, 77 (3): PP. 171-8, 1991.

10- BALTZER A.W.1, OSTAPCZUK M.S.2,3 and STOSCH D.: Positive effects of low level laser therapy (LLLT) on Bouchard's and Heberden's osteoarthritis. Lasers. Surg. Med. Feb. 2 Jul.; 48 (5): 498-504. Doi: 10.1002/lsm.22480. Epub, 2016

11- SANDRA B., VAN OS. NICK A., TROOP, KEITH R., et al.: Adherence to Prophylaxis in Adolescents and Young Adults with Severe Haemophilia: A Quantitative Study with Patients. Journal.Pone. Jan. 19; 12 (1), 2017.

12-KARIM M.A., SIDDIQUE R., JAMAL C.Y., et al.: Clinical profile of haemophilia in children in a tertiary care hospital. Bangladesh J. Child Health, 37: 90-6, 2013.

13- ALJASSER M.I., SLADDEN C., CRAWFORD R.I. and AU S.: Bullous pemphigoid associated with acquired hemophilia a: A rare association of autoimmune disease. J. Cutan. Med. Surg., 18: 123-6. Doi: 10.2310/7750.2013. 13060, 2014.

14- HEYWORTH B.E., SUTYG E.P., FIGGIE M.P., et al.: Orthopedic management of hemophilia. Am. J. Orthop., 34 (10): 479-86, 2005.

15- NUSS R., KILCOYNE R., GERAGHTY S., SHROYER A., ROSKY J., MAWHINNEY S., WIEDEL J. and MANCO-JOHNSON M.: MRI findings in hemophilic joints treated with radiotherapy with development of an MRI scale of joint damage. Hemophilia, 6: 162-9, 2000.
16- DYSON M.: Ultrasound for wound management: Clinical wound management, stack incorporated, USA, 197-204, 2008.

17- VLADMIROV Y.A., OSIP A.N. and KLEBANOV G.L.: Photobiological Principles of therapeutic applications of laser radiation. Biochemistry (Moscow), 69 (1): 81-90, Principles, 2004.

18- DAVID D., NGUYEN M. and KATRIN T.: Evaluation and management of hereditary hemophilia in the Emergency Department. Journal of Emergency Nursing, 19 (6): 225-30, 2008.

19- SAITO S. and SHIMIZU N.: Stimulatory effects of low power laser irradiation on bone regeneration in midpalatal suture during expansion in the rat. Am. J. Orthod. Dentofacial. Orthop., 111 (5): 525-32, 2008.

20- CONLAN M.J., RAPLAY J.W. and COBB C.M.: Biostimulation of wound healing by low-energy laser irradiation. J. Clin. Periodontol., 23: 492-6, 2007.

21- LARAIA E.M., SILVA I.S., PEREIRA D.M., DOS REIS F.A., ALBERTINI R., De ALMEIDA P., LEAL JUNIOR E.C. and De TARSO CAMILLO De CARVALHO P.: Effect of low-level laser therapy $(660 \mathrm{~nm})$ on acute inflammation induced by tenotomy of Achilles tendon in rats. Photochem. Photobiol., 88: 1546-50, 2012.

22- JAN MAGNUS BJORDAL, CHRISTIAN COUPPE and ANNE ELISABETH LJUNGGREN: Low Level Laser Therapy for Tendinopathy. Evidence of A Dose-Response Pattern. 6: 91-9, 2013

23- HUSMANN M.J., BARTON M., JACOMELLA V., et al. Long-term effects of endovascular angioplasty on orthostatic vasocutaneous autoregulation in patients with peripheral atherosclerosis. J. Vasc. Surg., 44: 993-97, 2006.

24- KAVROS S.J., DELIS K.T., TURNER N.S., et al.: Improving limb salvage in critical ischemia with intermittent pneumatic compression: A controlled study with 18-month follow-up. J. Vasc. Surg., 47: 543-49, 2008.

25- De HARO J., ACIN F., FLOREZ A., et al.: A prospective randomized controlled study with intermittent mechanical compression of the calf in patients with claudication. $\mathrm{J}$. Vasc. Surg., 51: 857-62, 2010.

26- R. ALBERTINI, A.B. VILLAVERDE, F. AIMBIRE M.A.C. SALGADO, J.M. BJORDAL C.D.L.P. ALVES, E. MUNIN and M.S. COSTA: Anti-inflammatory effects of low-level laser, 2007.

27- WEINTRAUB M.: Magnetic biostimulation in painful diabetic peripheral neuropathy: Anovel intervention-a randomized, double-placepo crossover studies. Am. J. Pain Manage, 9: 8-17, 2003.

28- ZISKIN M., Mc DIARMID T. and MICHLOVIS S.: Effects of ultrasound on electrical pain threshold perception in humans. Ultrasound Med. Biol., 13: 349-50, 2007. 


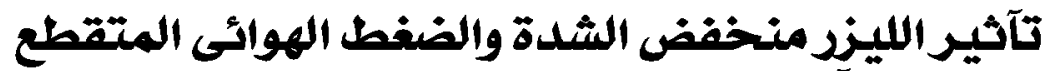

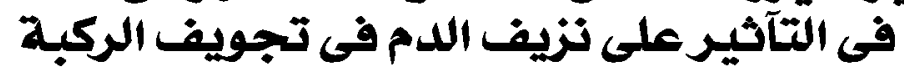 عند الآطفال المصابين بسيولة الدم الديم الركي}

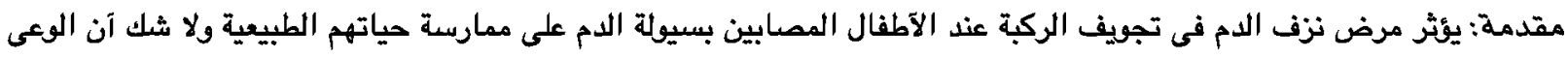
بالمرض والإهتمام بالعلاج من آهم عوامل حماية المصابين بهذا المرض من من المضاعفات الإعاقة الحركية.

الهدف من البحث: دراسة فاعلية الليند منففض الشدة والضغط الهوائى المتقطع فى التآثير على نزيف الدم فى تجويف الركبة عند الآطفال المصابين بسيولة الدم. الهدف:

الطريقة: تم إجراء البحث على • ع طفلا ممن يعانون من نزف الدم في تجويف الركبة نتيجة الإصابة بمرض سيولة الدم وتتراوح آعمارهم

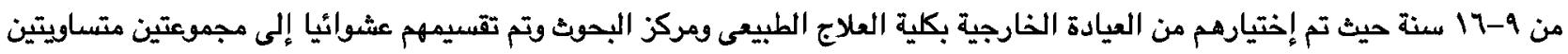

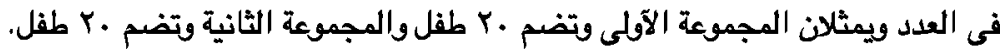

الهجموعة الآولى: تلقت المجموعة الآولى برنامج علاجى مكن من الموجات فوق الصوتية ويعد ذلك مجموعة من التمرينات العلاجية المختارة

$$
\text { وهى (تمرينات التقوية - تمرينات الإطالة). }
$$

المجموعة الثانية: تلقت مجموعة الثانية بالليزر منخفض الشدة والضغط الهوائى المتقطع بالإضافة إلى ما تلقته المجموعة الآولى من برنامع علاجى

القياسات: آجريت القياسات لهاتين المجموعتان قبل وبعد القترة العلاجية والتى آمتدت ثلاثة آشهر.

نتائج البحث: آثبت التحليل الإحصائى وجود تحسن ذو دلالة إحصائية واضحة لمرضى المجموعتين عند المقارنة بين النتائج قبل وبعد

العلاج لكل مجموعة كذلك وجد فروق ذات دلالة إحصائية بين المجموعتين بعد العلاج فى صالع مجموعة الدراسة. 